\title{
Relation of ground water to stream flow at Battle Creek, Mich.
}

\section{By G. E. Eddy and J. G. Ferris Februery 1950}

This is a summary of stetements made by G. E. Eddy, State Geologist of Michigan, and J. G. Ferris, district engineer, Ground Ve.ter Branch; U. S. Geological Survey, Lansing, Mich., in a conference during the fell of 1949 with John Spoden, Chief of the liaintenance and Flood Control Division of the district office of the Corps of Engineers, Milwaukee, Wis. The conference related to the probeble effect on groundwater conditions at Battle Creek of flood-control measures proposed by the Corps of Engineers.

The principal aquifer in the Battle Creek area is the Marshell sandstone, which ranges in thickness from 100 to perheps 150 feet through the greater part of the metropolitan area, except in the southwest and east-central parts of the city where the sandistone was rêmoved by a preglacial stream. Ground water in the Harshell sandstone occurs under artesiar conditions, the piezometric surface ranging from about the stage of the Kelamazoo River tofás much as 30 feet above this stage. At numerous places elong the courses of Battle Creek and the Kalamazoo River the Marshall sandstone crops out at or near river level. The available information suggests that hydraulic interconnection exists between the ground water of the Yarshall sandistone and the surface water of Battle Creek and the Kalamazoo River. However, until the completion of present'studies in the Battle Creek area, it would be difficult to prove rigidly the extent and degree of such interconnection.

When hydraulic interconnection exists between a stream and an aquifer, the level of that stream is a determining factor in the amount of inflow to or sutflow from the aquifer. The proposed lowering of the base-flow stage of the Kalamazoo River through the central part of Battle Creek may effect important changes in ground-water l.evel, ground-water discharge, and the performance of some well.s. The degree end extent of these changes will vary with time and with distance from the stream channel. In addition to the trensmission and storage properties of an aquifer, the drawdown of a riverside well depends upon the rate of pumping, the distance of the well from the stream, the permeability of the stream channel, the temperature of the water, and the stage of the stream. If all other factors are assumed constant, for a given stream stage a specific gradient is established between the stream and the well to satisfy the rate of pumping and this sradient determines the pumping level in the well. If all other factors are held constant and the stage of the stream is lowered, then the pumping level in the well is also lowered.

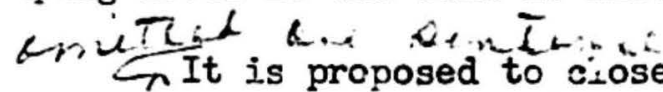
and and open a new course from the yonroe Street dam to the Ka]amazoo River. If we assume hydraulic interconnection betiseen the stream channel and the underlying Marshall sandstone, we can infer that present gl'ound-water developments along the existing channel that depend in any large degree 
upon the infiltration of stream water must necessarily pump future water supplies from somewhat increased depths. With the closing of the present channel, nearby wells would draw down to lower levels to provide the necessery gradient to move water from other and more distant sources of recharge. For wells elong the course of the proposed channel, the distances from recharge source to well site would be decreased. If such decreases are appreciable, pumping levels at these well developments would be raised to more economical stages. Thus, we nay infer thet benefits might, accrue to wells along the course of the new channel, whereas wells, close to the abandoned channel might reguire increased

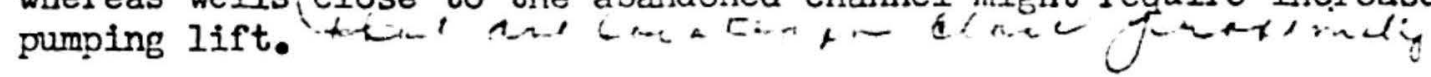

lost wells in the Battle Creek area that are finished in the Marshall sandstone are drilled through the full thichness of this formation. Static levels are relatively close to the surface and large yields with limited drawdowm are co:mon. However, wells that are presently operating with pump settings et or near the limits of existing pumping equipment will either break suction or decline in yield if water levels ${ }^{2}{ }_{\ldots} \ldots$ are lovered. lost large-capacity wells of recent construction are equipped with deep-well turbine purps with bow? settings at moderato depths, and for many existing wells in this area several feet of lowering in pumping level probably would not require any major change of present pumping equipment.

An important consideration in the plenning of proposed floodcontrol inprovements in th. Battle Creek area is the effect of lowered base-flow suage on regional ground-water levels and ground-water discharge. For some time following the lowering of base stage the discharge of vater from the Yarsinall sandstone to Battle Creek and the Kalamazoo River may be increased appreciably. In view of' the high permeability of the sandstone as shown by the large yields of wells per foot of drawdown in this aree, it can be expected that a lowering of base stage will result in a substantial increase in the base flow of these streams. If changes in base flow are important to the planning of the Corps of Engineers, it would be desirable to obtain quantitative data on the transmission capacity of the Marshall sandstone and on the bearing of these data and other hydrologic factors on the probable veriations of bese flow with time as the result of lowering bese-flow stage.

The restoration of equilibrium between recharge and discharge in the sandstone aquifer to meet the proposed chenge in head on the discharge outcrop may require considerable time. Important cinanges in the position of the regional divides of the ground-water basin may result. Any quantitative appraisal. of the magnitude of the various effects of the proposed flood-control improvenent on existing well developments or on springs and streams in the Battle Greek area would require a comprehensive hyaro-geologic investigation. 